\title{
Effect of complex modification on cement compositions
}

\author{
Irina Enzhievskaya ${ }^{1}$, Cyril Odintsov $^{1}$, and Maxim Chekhlov $^{1, *}$ \\ ${ }^{1}$ Siberian Federal University, 660041, Svobodny ave., 79, Krasnoyarsk, Russia
}

\begin{abstract}
The article deals with the modification of cement compositions by a complex of modifiers, including superplasticizers and finely dispersed mineral fillers (micro fillers), based on local raw materials and by-products of the industry, as well as being capable of improving the physical and mechanical characteristics of cement concretes and solutions. The expediency of joint application of finely dispersed fillers and superplasticizers for obtaining materials with high performance characteristics is shown. The studies described in the article are aimed at expanding the raw materials base of mineral additives in combination with superplasticizers and studying their behavior in the cement system. As finely dispersed mineral additives, the following were used in the work: ground limestone from the overburden from the Mazulsky deposit, waste from sawing the jadeite of the Kashkaraksky deposit, a pulverized fraction of waste from crushing the Berezovskoye gravel, and Novosibirsk microsilica. It is shown that the introduction of the waste from sawing jadeite into the composition of the cement, along with microsilica, leads to increasing strength at bending and compression at 28 days. In the process of manufacturing a concrete and mortar mixture with the addition of limestone flour, increased gas emission was visually observed. The interaction was observed between the finely dispersed limestone flour with additives of plasticizing effect with the observed emission of complex gases, such as ammonium hydroxide, ammonium nitrate, and others.
\end{abstract}

In connection with the continuous development of building technologies and new methods of erecting buildings, as well as high requirements for concrete, mortars, dry building mixtures, and other cement compositions, it becomes necessary to develop compositions that meet technical requirements and economic efficiency. The strategy for the development of modified cement compositions with high technological, operational properties and guaranteed quality indicators corresponds to the latest regulations of the Government of the Russian Federation, the Ministry of Construction and Housing of the Russian Federation on the development of composite materials. Creating concretes and mortars with the specified functionality of a maintenance-free service life for 50 years and more in the specific conditions of Siberia and the Far East is an important problem of contemporary construction. Such compositions cannot be obtained without a complex of modifiers, including fine-

\footnotetext{
*Corresponding author:m.chehlov@yandex.ru
} 
dispersed mineral fillers (micro fillers) and superplasticizers. The search for new mineral additives based on local raw materials and by-products of the industry, which at the same time can improve the physical and mechanical characteristics of cement materials, is an urgent task.

Currently in Russia, there is a significant amount of scientific developments in the use of associated products in order to improve the quality of building materials. Yu. M. Bazhenov, M. N. Moroz, V. I. Kalashnikov, I. V. Erofeeva, Sh. N. Iohan work in the direction of expanding the raw material base for the production of concretes, mortars, and dry construction mixtures [1, 2, 3]. In the papers [4-8], the chemical interaction of modifier additives in the cement system, their plasticizing and structuring effect on the strength, and performance properties were evaluated. A resource-saving effect from the use of modifying additives was also considered [9], along with the questions of improving the quality of concretes [17].

The issues of complex modification of cement compositions and the use of industrial byproducts for this purpose are devoted to a number of scientific developments [10-13]. The most famous is the experience of using microsilica in the technology of making concrete [14].

In the papers [18, 19], composite binder materials for fine-grained self-compacting concretes were considered. The mechanism of increasing the concrete strength with the introduction of micronutrients was considered in [20].

The increasing quality of cement composites using associated raw materials and industrial wastes was carried out by such foreign scientists as Jeknavorian, A., Roberts, L., Jardine, L., and Souquir, Z. [15, 16]. A review of foreign experience shows that the use of superplasticizers is increasingly applied in improving the quality of building materials [15, 16].

In connection with the foregoing, the current task of the modern concrete strategy is to expand the resource base of fine mineral additives (fillers) in combination with superplasticizers and study their behavior in the cement system.

The research has the following objective: to study the system of finely dispersed mineral additives (based on local raw materials) and associated industrial products in combination with superplasticizers in the production of cement compositions with prescribed high physical and mechanical characteristics, focusing the influence they have on the components of the cement system in materials such as concretes and mortars.

The implementation of complex projects in contemporary construction requires the development of compounds that cannot do without chemical additives. A set of modifiers, such as finely divided mineral fillers and superplasticizers, was used in the research. It should be noted that the composition of the majority of complex organomineral additives is formed empirically, without taking into account the features of the crystal lattices of finely dispersed mineral fillers, the chemical structure of the modifier molecules, and the nature of their behavior in the hydrated cement system. One of the most important tasks of the theory of building materials science is to investigate the mechanisms of interaction of micro fillers and hydrate phases of cement systems during hardening. It is impossible to unambiguously characterize this mechanism, since in a complex and multicomponent hydrating cement system, there are a number of factors that affect the nature and kinetics of chemical and crystallization processes.

Currently, the most common mineral additive used in the technology of concrete is microsilica; other finely dispersed materials are also used (with the fineness of grinding close to cement).

The mining and processing industries have accumulated a huge amount of waste production of natural and technogenic origin, containing silica, carbonate, and other components, the use of which in the technology of concretes, mortars, and dry mortars is 
economically and environmentally appropriate. The most effective are mineral fillers, such as finely divided stone flour, which, along with high rheological capacity with respect to superplasticizers, may have chemical activity in the hydrated cement system.

As finely dispersed mineral additives, the studies used were: ground limestones from the overburden from the Mazulsky deposit, waste from sawing the jadeite of the Kashkaraksky deposit, a pulverized fraction of the waste during the crushing of gravel from the Berezovsky deposit, and the Novosibirsk microsilica. Table 1 shows the chemical composition of mineral additives.

Table 1. Chemical composition of mineral fillers.

\begin{tabular}{|c|c|c|c|c|c|c|c|c|c|c|}
\hline \multirow{2}{*}{$\begin{array}{l}\text { Type of } \\
\text { a filler }\end{array}$} & \multicolumn{10}{|c|}{ Oxide content, \% } \\
\hline & $\mathrm{SiO}_{2}$ & $\mathrm{Al}_{2} \mathrm{O}_{3}$ & $\mathrm{Fe}_{2} \mathrm{O}_{3}$ & $\mathrm{MgO}$ & $\mathrm{CaO}$ & $\mathrm{SO}_{3}$ & $\mathrm{Na}_{2} \mathrm{O}$ & $\mathrm{K}_{2} \mathrm{O}$ & $\mathrm{TiO}_{2}$ & p.p. \\
\hline $\begin{array}{c}\text { Limestone } \\
\text { flour of the } \\
\text { Mazulsky } \\
\text { deposit }\end{array}$ & 2,88 & 1,6 & 1,19 & 7,9 & 76,56 & 0,67 & - & - & - & 9,2 \\
\hline $\begin{array}{l}\text { Dusty fraction } \\
\text { of waste } \\
\text { during } \\
\text { crushing } \\
\text { gravel of the } \\
\text { Berezovsky } \\
\text { deposit }\end{array}$ & 74 & 10 & 3,5 & 2,2 & 3 & 0,3 & 2 & 1 & 0,1 & 3,9 \\
\hline $\begin{array}{c}\text { Wastes from } \\
\text { sawing the } \\
\text { Jadeite of the } \\
\text { Kashkaraksky } \\
\text { deposit }\end{array}$ & 57,6 & 20,3 & 2 & 1,2 & 2,1 & - & 11,7 & - & 0,2 & 4,9 \\
\hline $\begin{array}{l}\text { Novosibirsk } \\
\text { microsilica }\end{array}$ & $\begin{array}{c}90- \\
92\end{array}$ & 0,7 & 0,7 & 1 & 0,8 & 0,3 & 0,6 & 1,2 & - & 2,7 \\
\hline
\end{tabular}

The limestone flour obtained from overburden of the Mazulsky limestone mine is mainly represented by calcite $\left(\mathrm{CaCO}_{3}, \mathrm{~d}=3,86 ; 3,03 ; 1,912 \AA\right.$, JCPDS, 47-1743). In subordinate quantities (up to $10 \%$ of the main phase), there are dolomite $\left(\mathrm{CaMg}\left(\mathrm{CO}_{3}\right)_{2}, \mathrm{~d}=2,89 ; 2,20\right.$; 2,01 Å, JCPDS, 36-426), kaolin $\left(\mathrm{Al}_{2} \mathrm{Si}_{2} \mathrm{O}_{5}(\mathrm{OH})_{4}, \mathrm{~d}=7,19 ; 3,59 ; 1,47 \AA\right.$, JCPDS, 6-201), and quartz $\left(\mathrm{SiO}_{2}, \mathrm{~d}=4,26 ; 3,34 ; 1,818 \AA\right.$, JCPDS, 5-490). It is also possible to observe the presence of small amounts of greenalite $\left(\mathrm{Fe}_{3}\left(\mathrm{Si}_{2} \mathrm{O}_{5}\right)(\mathrm{OH})_{4}\right.$, JCPDS, 39-337) and clinochlore $\left((\mathrm{Mg}, \mathrm{Al})_{6}(\mathrm{Si}, \mathrm{Al})_{4} \mathrm{O}_{10}(\mathrm{OH})_{8}, \mathrm{JCPDS}, 16-351\right)$.

The original rock waste from sawing he jadeite of the Kashkaraksky deposit is represented by crystals of light greenish-gray color and of the coarse-grained massive texture and granoblastic structure. Pore-forming minerals, $\%$ m.: jadeite -95 , albite -4 , analcime -1 , secondary zeolite.

The data of the mineralogical analysis are confirmed by X-ray diffraction; it is shown in Figure 1.

Over the course of our research, we selected the compositions of solutions and concretes with high performance characteristics that can be used in construction in specific areas of Siberia and the Far East. The studies were carried out using the Krasnoyarsk portland cement CEM I $42.5 \mathrm{~N}$. The chemical-mineralogical composition and properties of the Krasnoyarsk cement are given in Tables 2 and 3.

As a fine aggregate, the quartz sand of the Peschanka deposit with the size module of $\mathrm{Mk}$ $=2.31$, being enriched with screening crumbs and washed with a content of dust and clay particles of less than $1 \%$. 
For the production of concrete, basalt rubble of fractions of 5-10 and 10-20 mm was used.

In laboratory conditions, samples of a solution (beads, $4 \times 4 \times 16 \mathrm{~cm}$ in size and cubes with an edge of $7.07 \mathrm{~cm}$ ) were prepared using various finely dispersed fillers in order to compare their physico-mechanical characteristics.

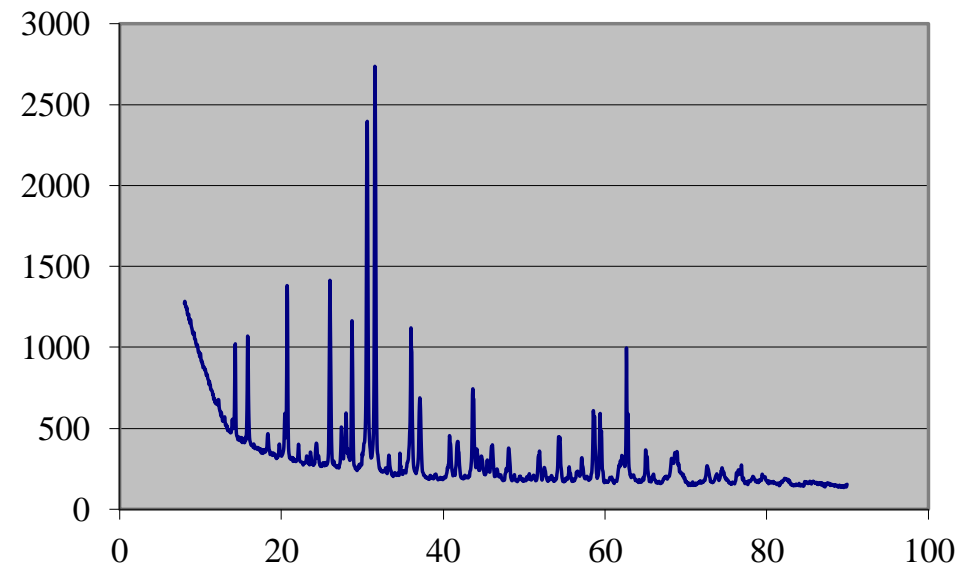

Fig. 1. Diffractogram of waste during sawing of the jadeite of the Kashkara deposit.

Table 2. Chemical composition of the cement.

\begin{tabular}{|c|c|c|c|c|c|c|}
\hline \multicolumn{7}{|c|}{ Chemical composition, \% } \\
\hline $\mathrm{SiO}_{2}$ & $\mathrm{Al}_{2} \mathrm{O}_{3}$ & $\mathrm{Fe}_{2} \mathrm{O}_{3}$ & $\mathrm{CaO}$ & $\mathrm{MgO}$ & $\mathrm{RO}_{2}$ & $\mathrm{SO}_{3}$ \\
\hline 19,8 & 4,97 & 3,99 & 62,9 & 2,1 & 0,52 & 2,7 \\
\hline
\end{tabular}

Table 3. Mineralogical composition of the cement.

\begin{tabular}{|c|c|c|c|c|c|c|}
\hline \multicolumn{7}{|c|}{ Mineralogical composition, \% mass } \\
\hline C3S & C2S & C3A & C4AF & $\mathrm{MgO}$ & CaSO4·2H2O & CaOcB. \\
\hline 62 & 10 & 6,4 & 12,1 & - & $3-5$ & $1-1,2$ \\
\hline
\end{tabular}

To make solutions based on dry building mixtures, a complex of additives was used: plasticizing on the basis of polycarboxylate esters PCE (superplasticizer Melflux $5581 \mathrm{~F}$ ) and microfillers, namely the limestone flour and waste from sawing the jadeite. Numerous experiments have determined the optimal consumption of fillers. The content of finely ground limestone is $35-37 \%$, the fine-grained jadeite is $33-37 \%$. Samples were tested at the age of 3 and 28 days. The test results are given in Table 4 .

As can be seen from Table 4, the introduction of jadeite into the waste composition results in the increasing compressive strength at the age of 28 days by $27 \%$ and bending strength by $26 \%$; for calcareous flour, the compression strength increases by $14 \%$, and the bending strength increases by $10 \%$ if compared with the control composition. With a higher degree of filling solutions with limestone flour and jadeite sawing waste (40-50\%), the strength dropped. In the process of making the mortar mixture with limestone flour visually, there was an increased gas emission.

The increase in physical and mechanical characteristics of solutions based on dry construction mixtures is due to the fact that mineral additives that do not enter the hydration reaction contribute to the formation of a stable rheological matrix of cement systems and to improve their technological properties. Due to the high efficiency of the superplasticizer in relation to mineral finely dispersed fillers, they allow to significantly reduce the amount of water in the filled systems and to obtain high density and strength. 
To determine the physical and mechanical characteristics of concretes, samples of cubes with an edge of $10 \mathrm{~cm}$ were made. In all concrete mixtures, a liquid plasticizer based on polycarboxylate esters (MC-Powerflow-7951) was used. The mechanism of action of the system of complex modifiers under study in concrete mixtures is based on the increase in the specific surface area of the constituent components of the cement paste and, in this connection, the volume of the adsorption water being firmly retained. This makes it possible to obtain the required amount of a test of the finely dispersed fraction, which ensures the formation of a sufficient thickness of the coating on the surface of the aggregate grains, and, accordingly, the production of the required workability of the mixture. The results of studies of concretes with various finely dispersed mineral fillers in the system are given in Table 5.

Table 4. Physical and mechanical characteristics of building mixtures.

\begin{tabular}{|c|c|c|c|c|c|c|}
\hline \multirow{2}{*}{ Type of filler } & \multirow{2}{*}{$\begin{array}{c}\text { Additive } \\
\text { consumpti } \\
\text { on micro } \\
\text { filler, \% }\end{array}$} & \multicolumn{2}{|c|}{$\begin{array}{c}\text { Compressive strength, } \\
\mathrm{MPa}\end{array}$} & \multicolumn{2}{|c|}{ Bending strength, $\mathrm{MPa}$} & \multirow{2}{*}{$\begin{array}{c}\text { Density of } \\
\text { the solution } \\
\mathrm{kg} / \mathrm{m}^{3}\end{array}$} \\
\hline & & 3 days & 28 days & 3 days & 28 days & \\
\hline $\begin{array}{l}\text { Control without } \\
\text { filler }\end{array}$ & 0 & 24,5 & 30,4 & 4,92 & 5,98 & 2050 \\
\hline $\begin{array}{c}\text { Limestone flour } \\
\text { of the Mazulsky } \\
\text { deposit }\end{array}$ & 37 & 32,3 & 35,6 & 6,15 & 6,65 & 2080 \\
\hline $\begin{array}{l}\text { Wastes from } \\
\text { sawing the } \\
\text { jadeite of the } \\
\text { Kashkaraksky } \\
\text { deposit }\end{array}$ & 37 & 33,8 & 41,8 & 8,17 & 8,07 & 2110 \\
\hline
\end{tabular}

Table 5. Physical and mechanical characteristics of concrete.

\begin{tabular}{|c|c|c|c|c|c|c|}
\hline \multirow{2}{*}{ Type of filler } & \multirow{2}{*}{$\mathrm{B} / \mathrm{C}$} & $\begin{array}{c}\text { Amount } \\
\text { of filler, } \\
\text { \% }\end{array}$ & & \multicolumn{2}{|c|}{ Concrete strength, MPa } & \multirow{2}{*}{$\begin{array}{c}\text { Density, } \\
\mathrm{ng} / \mathrm{m}^{3}\end{array}$} \\
\hline Control without filler & 0,40 & - & 22,7 & 28,5 & 35,5 & 2390 \\
\hline $\begin{array}{c}\text { Pulverized fraction of } \\
\text { waste during crushing } \\
\text { of gravel }\end{array}$ & 0,37 & $6-7$ & 23,3 & 28,8 & 37,3 & 2410 \\
\hline Novosibirsk microsilica & 0,38 & 6 & 23,7 & 40 & 48,3 & 2420 \\
\hline $\begin{array}{c}\text { Limestone flour of the } \\
\text { Mazulsky deposit }\end{array}$ & 0,39 & $6-7$ & 23,2 & 29,0 & 36,9 & 2410 \\
\hline $\begin{array}{c}\text { Wastes from sawing } \\
\text { the jadeite of the } \\
\text { Kashkaraksky deposit }\end{array}$ & 0,37 & $6-7$ & 25,1 & 38,3 & 48,0 & 2450 \\
\hline
\end{tabular}

Analysis of the results presented in Table 5 shows that the introduction of waste into the concrete composition during sawing of jadeite and microsilica leads to an increase in the compressive strength at the age of 28 days by $26 \%$ if compared to the control composition. The use of these finely dispersed fillers makes it possible to obtain a cement matrix of high density, promotes the hydration of clinker minerals, can significantly change the charge state of cement particles, thereby transforming not only the rheological state of the system, but also the nature and speed of the hydration processes, which leads to the formation of stable high-strength structures in a cement stone. The use of the pulverized fraction of waste during the crushing of the gravel from the Berezovsky deposit leads to a decrease in the consumption of the cement binder in the system, as well as for other fillers, but strength does not increase 
significantly. In the composition with limestone flour, the mechanism of action of the microfiller is the structure-forming effect of the particle surface as a substrate for the oriented crystallization of neoplasms. In the process of manufacturing a concrete mixture with this filler, there was also a visual increase in gas emissions.

To analyze the effect of plasticizing additives on limestone flour, the modifiers based on naphthalene sulfonates (Polyplast SP-1), polycarboxylate esters (MC-Powerflow-7951), and technical lignosulfonate (Centrament N10) were added to the limestone weighed (Figure 2).

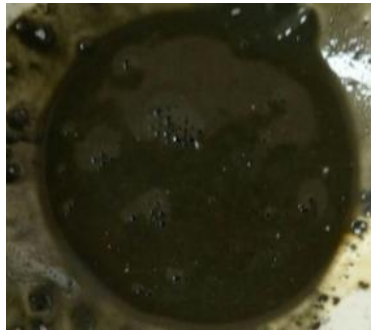

a)

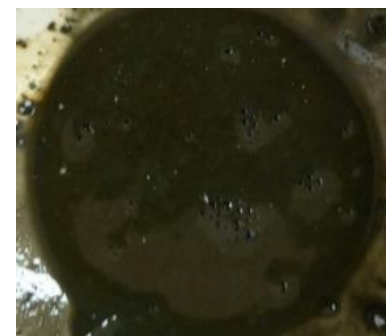

b)

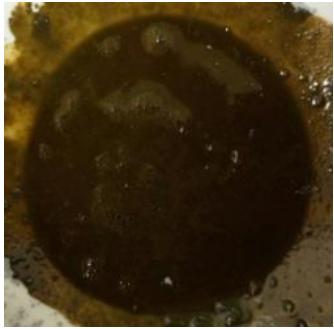

c)

Fig. 2. Gas emissions from a mixture of calcareous flour with plasticizing additives: a - Polyplast SP1; b-MC-Powerflow-7951; c-Centrament N10.

In photographs, the process of gas emission is visually observed when limestone additives of all kinds are used.

The gases were collected and examined in a gas analyzer. Preliminary results showed the presence of the following gases:

- In samples with additives based on technical lignosulfonate and naphthalene sulfonates were detected: $\mathrm{NH}_{4} \mathrm{OH}$ - ammonium hydroxide $\left(0.3 \mathrm{ml} / \mathrm{dm}^{3}\right) ; \mathrm{NH}_{4} \mathrm{NO}_{3}$ - ammonium nitrate $\left(0.005 \mathrm{ml} / \mathrm{dm}^{3}\right) ; \mathrm{CO}\left(\mathrm{NH}_{2}\right)_{2}-$ urea $\left(0.01 \mathrm{ml} / \mathrm{dm}^{3}\right)$;

- In the sample with polycarboxylate ethers were found: $\mathrm{Ca}_{5} \mathrm{NH}_{4}\left(\mathrm{NO}_{3}\right)_{11}$ - ammonium form of calcium nitrate $\left(0,01 \mathrm{ml} / \mathrm{dm}^{3}\right) ; \mathrm{NH}_{4} \mathrm{OH}$ - ammonium hydroxide $\left(0,3 \mathrm{ml} / \mathrm{dm}^{3}\right)$.

Further research is planned to find a solution to the problem of neutralizing these gases in the presence of limestone in the cement system.

Based on the studies carried out, the following conclusions can be made:

- A number of finely dispersed mineral additives based on local raw materials and associated industrial products in combination with superplasticizers in the production of cement compositions with prescribed high physical and mechanical properties were studied. The highest strength parameters were achieved in compositions using jadeite and microsilica.

- The effect of additives on the components of the cement system in such materials as concretes and solutions was evaluated. The interaction of limestone flour with additives of plasticizing effect with the observed gas emissions was revealed. A preliminary analysis of these gases indicated the presence of: $\mathrm{NH}_{4} \mathrm{OH}$ - ammonium hydroxide $\left(0.3 \mathrm{ml} / \mathrm{dm}^{3}\right)$; $\mathrm{NH}_{4} \mathrm{NO}_{3}$ - ammonium nitrate $\left(0.005 \mathrm{ml} / \mathrm{dm}^{3}\right) ; \mathrm{CO}\left(\mathrm{NH}_{2}\right)_{2}$ - urea $\left(0.01 \mathrm{ml} / \mathrm{dm}^{3}\right)$ when introducing additives based on technical lignosulfonate and naphthalene sulfonates, and $\mathrm{Ca}_{5} \mathrm{NH}_{4}\left(\mathrm{NO}_{3}\right)_{11}$ - ammonium form of calcium nitrate $\left(0.01 \mathrm{ml} / \mathrm{dm}^{3}\right) ; \mathrm{NH}_{4} \mathrm{OH}$ - ammonium hydroxide $\left(0.3 \mathrm{ml} / \mathrm{dm}^{3}\right)$ when using additives of polycarboxylate esters:

- A similar effect is possible in cement systems, in which there is a mineral admixture of limestone flour in the binder.

\section{References}

1 Yu. M. Bazhenov, Technology of Concrete, 5, 468 (2002) 
2 M. N. Moroz, V. I. Kalashnikov, I. V. Erofeeva, Effective concrete of a new generation with low specific consumption of cement per unit strength, 6, 189-191 (2015)

3 Sh. N. Iokhan, V.G. Vikht, Durability of concrete (Oranta, Kiev, 2004)

4 O. L. Dvorkin, Efficiency of chemical additives in concretes, 4, 23-25 (2003)

5 V. G. Batrakov, Modified concrete. Theory and practice, 1, 768 (1998)

6 V. G. Batrakov, S. S. Sheinfeld, E. S. Silina, Modified concrete in the practice of modern construction, 9, 23-25 (2002)

7 N. A. Shapovalov, V. A. Lomachenko, A. A. Slyusar, M. M. Kosukhin, S. M. Shemetova, Superplasticizers for concrete, 29-31 (2001)

8 Z. A. Kamalova, R. Z. Rakhimov, E. Yu. Ermilova, O. V. Stoyanov, Bulletin of the Kazan Technological University, 8 (2013)

9 V. G. Batrakov, M. Sh. Finer, Concrete and Reinforced Concrete, 3, 3-5 (1991)

10 S. A. Vysotsky, Concrete and Reinforced Concrete, 2, 7-10 (1994)

11 V. K. Vlasov, Concrete and Reinforced Concrete, 10, 9-11 (1998)

12 S. A. Dergounova, V. N. Rubtsov, Proceedings of the Higher Educational Institutions. Building, 11-12, 34-41 (2005)

13 G. V. Nesvetaev, G. S. Kardumyan, L. A. Khomich, A. M. Blugoz, New Technologies, 4 (2012)

14 M. S. Dubensky, A. A. Kargin, Chemical Technology, 1-2 (2016)

15 A. Jeknavorian, L. Roberts, L. Jardine, Proceeding Fifth CAN-MET/ACI Int. Conference, 173-4 (1997)

16 C. Giraudeau, J. B. d`Espinose de Lacaillerie, Z. Souquir, A. Nonat, R. J. Flatt, Surface and intercalation chemistry of polycarboxylate copolymers in cementitious systems. J. Am. Cer. Soc., 92(11), 471-2488 (2009)

17 V. R. Falikman, Advances in Admixture Technology, 41-46 (2005)

18 A. K. Dyatlov, A. I. Kharchenko, M. I. Bazhenov, I. Ya. Kharchenko, Concrete Technology, 3, 40-43 (2013)

19 A. V. Volzhensky, Yu. S. Burov, V. S. Kolokolnikov, Mineral astringents (Stroyizdat, Moscow, 1973)

20 I. M. Red, Concrete and Reinforced Concrete, 5, 10-11 (1987)

21 G. G. Dubrovina, Yu. A. Goncharov, A. G. Gubskaya, D. V. Nazarov, Cement dry building mixtures. Innovations in production and application (Kovcheg, Minsk, 2015) 